\title{
Intra-tumoural microvessel density in human solid tumours
}

\author{
J Hasan', R Byers ${ }^{2}$ and GC Jayson*,I \\ 'Cancer Research UK Department of Medical Oncology, Christie Hospital, Wilmslow Road, Withington, Manchester M20 4BX, UK; ${ }^{2}$ Department of \\ Pathological Sciences, University of Manchester, Oxford Road, Manchester MI 3 9PT, UK
}

\begin{abstract}
Over the last decade assessment of angiogenesis has emerged as a potentially useful biological prognostic and predictive factor in human solid tumours. With the development of highly specific endothelial markers that can be assessed in histological archival specimens, several quantitative studies have been performed in various solid tumours. The majority of published studies have shown a positive correlation between intra-tumoural microvessel density, a measure of tumour angiogenesis, and prognosis in solid tumours. A minority of studies have not demonstrated an association and this may be attributed to significant differences in the methodologies employed for sample selection, immunostaining techniques, vessel counting and statistical analysis, although a number of biological differences may account for the discrepancy. In this review we evaluate the quantification of angiogenesis by immunohistochemistry, the relationship between tumour vascularity and metastasis, and the clinicopathological studies correlating intra-tumoral microvessel density with prognosis and response to anti-cancer therapy. In view of the extensive nature of this retrospective body of data, comparative studies are needed to identify the optimum technique and endothelial antigens (activated or pan-endothelial antigens) but subsequently prospective studies that allocate treatment on the basis of microvessel density are required.
\end{abstract} British Journal of Cancer (2002) 86, I566- 1577. DOI: 10.1038/sj/bjc/66003I5 www.bjcancer.com (C) 2002 Cancer Research UK

Keywords: microvessel density; angiogenesis; solid tumours

Angiogenesis is the process in which new blood vessels arise from existing ones. This is present physiologically in the adult during wound healing, the development of the ovarian follicle and corpus luteum and in the proliferating endometrium. Pathological angiogenesis is also a component of much diverse pathology ranging from diabetes and atherosclerosis to cancer, a disease that cannot progress without the formation of new blood vessels (Folkman, 1972).

The measurement of angiogenesis is complicated by the fact that it is a dynamic process yet most studies to date have focused on the product of angiogenesis, the microvessel density, which was analysed at a particular point in time. Accepting this caveat there are extensive data in which the microvessel density correlates with metastasis and survival. Here, we discuss the relationship between angiogenesis and the intra-tumoural microvessel density (IMD), review the different techniques that have been used to measure IMD and then discuss the reasons why this relationship does not always hold.

\section{IMD AS A MEASURE OF TUMOUR ANGIOGENESIS}

As angiogenesis is a dynamic process, comparisons with snapshot views of the tumour, as are seen in biopsy analyses, are not straightforward. On the other hand the only approaches that are available in the clinic for the serial measurement of tumour angiogenesis involve molecular imaging strategies, such as contrastenhanced magnetic resonance imaging (MRI) and positron emission tomography (PET), that do not resolve data at the

*Correspondence: Dr G Jayson; E-mail: GordonJayson@aol.com

Received 23 January 2002; accepted 21 March 2002 microscopic level. Thus it is important to assess the relationship between IMD and angiogenesis.

Several studies have reported correlations between IMD and angiogenic growth factor expression, tumour growth and the occurrence of distant metastasis suggesting that IMD, as well as quantifying vascular density, reflects important information on the degree and function of tumour vasculature.

\section{IMD and angiogenic cytokine expression}

Several clinicopathological studies have shown a direct association between angiogenic cytokine expression and IMD. Vascular endothelial growth factor (VEGF) expression has been shown to correlate with microvessel density in a number of solid tumours including prostate (Weidner et al, 1993), colon (Takahashi et al, 1995), lung (Mattern et al, 1996) and breast cancer (Linderholm et al, 1999). Toi et al (1995a) compared IMD with VEGF and PdEGF (platelet-derived endothelial cell growth factor) expression in 152 invasive breast cancer specimens. VEGF and PdEGF expression were significantly correlated with the increase in IMD, and in another study intra-tumoural VEGF concentrations in 135 breast cancer tissue homogenates were significantly higher in richly vascularised tumours as opposed to the ones that were poorly vascularised. (Toi et al, 1996). VEGF concentrations measured by ELISA in the tumour tissue from 19 brain tumour patients were significantly correlated with vascular density (Takano et al, 1996). Almost all tumour cells in the peripheral areas of brain tumours that contained a high amount of VEGF protein were associated with increased IMD on immunohistochemical staining.

Significant correlation between VEGF expression and IMD has also been reported for gastric (Maeda et al, 1996), endometrial (Giatromanolaki et al, 2001) and cervical cancer (Guidi et al, 1995). 
The clinical importance of VEGF is emphasised by the fact that VEGF inhibition has been shown to significantly inhibit angiogenesis and tumour growth in in vivo models (Kim et al, 1993; Saleh et al, 1996). Consequently anti-VEGF agents are being developed as therapeutic strategies to inhibit tumour angiogenesis and progression. Clearly these cytokines act through specific signalling receptors and recent data have shown a relationship between cytokine concentration, signalling receptor and IMD. In a series of 121 endometrial carcinomas, VEGF expression was associated with increased angiogenesis and poor prognosis, but more importantly its expression was linked with an increased density of vessels expressing the KDR (kinase domain region) receptor at the invading tumour front. VEGF expression in the absence of VEGF/KDR-activated vasculature was a less important predictor of poorer survival, suggesting that the prognostic importance of VEGF is significantly improved when the combined VEGF/KDR status is assessed (Giatromanolaki et al, 2001).

A positive correlation between IMD and other angiogenic cytokines like basic fibroblast growth factor (bFGF) has also been reported ( $\mathrm{Li}$ et al, 1994; Riedel et al, 2000; Sugamoto et al, 2001). However, several studies failed to find any correlation between bFGF and IMD and have questioned its relevance as an independent prognostic factor (Burian et al, 1999; Schmidt et al, 1999; Smith et al, 1999). It has been hypothesised that bFGF has a role only when it synergises with other growth factors like VEGF. Thymidine phosphorylase (TP or PDECGF), another important angiogenic factor, is an intracellular enzyme involved in pyrimidine metabolism, neural function and neovascularisation (Brown et al, 1998). One of its metabolites 2-deoxy-D-ribose is a potent mediator of angiogenesis (Folkman, 1996). The prognostic value of TP has been recognised in breast cancer (Fox et al, 1996, 1997a) and a correlation between TP expression and IMD has been reported for other solid tumours (Toi et al, 1995a; Matsuura et al, 1999; Ueda et al, 1999).

\section{IMD and UPA/PAI-1 levels}

Background extracellular matrix proteolysis is one of the most important steps in angiogenesis. The urokinase-type plasminogen activator system (uPAS) consisting of urokinase plasminogen activator (uPA), an extracellular proteolytic enzyme produced by tumour cells, its receptor UPA-R and their corresponding inhibitors plasminogen activator inhibitors 1 and 2 (PAI-1 and PAI-2) are thought to play a major role in this process. uPA at the cell surface initiates a proteinase cascade leading to the breakdown of the extracellular matrix and thereby promoting cellular migration. The levels of uPA and its inhibitor PAI-1 are known prognostic factors in breast cancer. In a series of patients with breast cancer, uPA and PAI-1 contents were measured by ELISA in tissue extracts, in peripheral and central tumour tissue (Hildenbrand et al, 1995). uPA and PAI-1 levels were higher in the peripheral breast tumour regions, particularly in node-positive patients and there was a linear correlation between $\mathrm{CD}^{+} 1^{+}$IMD and uPA/PAI-1 levels.

Although these studies have demonstrated a correlation between particular angiogenic factors and IMD, there have been very few attempts to examine multiple angiogenic and anti-angiogenic factors in conjunction with IMD and clearly more work is needed in this area.

\section{IMD and intra-tumoural microvascular characteristics}

It is of particular interest to know the degree to which the radiological assessment of tumour vasculature correlates with IMD. A number of techniques exist to assess this, including contrast enhanced magnetic resonance imaging (MRI) (Brasch et al, 2000; Brasch and Turetschek, 2000; Anderson et al, 2001) colour
Doppler ultrasound (Huber et al, 1994; Delorme and Knopp, 1998; Cheng et al, 1999) and positron emission tomography (Fanelli et al, 1999; Anderson et al, 2001). There is some evidence to show that radiological imaging can detect differences in IMD. In one study slow and fast growing subtypes of a R3230 mammary carcinoma were implanted into mice and were subsequently analysed for both IMD by FactorVIII-related-antigen (FVIII-RA) and plasma volume. MR imaging-derived tumour plasma volume and permeability increased exponentially with increased capillary density. A more densely structured vasculature was found in the fast growing tumours and the increased vascular density correlated with estimates of plasma volume as assessed by MRI (van Dijke et al, 1996). However, in human studies these correlations have not been so strong, for instance, in a recent study of cervical carcinoma there was no clear relationship between MRI and IMD (Cooper et al, 2000). On the other hand a study in glioma, where VEGF has been more strongly implicated in the tumour's pathogenesis, did identify a relationship between MRI findings and IMD (Tynninen et al, 1999).

\section{QUANTIFICATION OF IMD BY IMMUNOHISTOCHEMISTRY}

Despite the fact that the majority of studies have identified IMD as an independent prognostic factor in solid tumours, several studies have questioned the finding. These discrepancies may be due to particular tumour biological factors that obscure the relationship but other issues such as staining methodology have also been implicated. In part the variation in the relationship between IMD and prognosis has arisen from a lack of standardised immunohistochemical techniques because of the wide range of antibodies, antigen retrieval methods, designation of high and low vessel count groups (cut-off points), patient groups, therapies and data (vessel quantification) interpretation. The correct identification of the vascular hot spot within the tumour and observer experience are two of the most important factors. In one study that compared the effects of different methodologies on estimates of tumour vascularity, archival specimens of breast, lung and oral carcinoma, oral dysplasia and normal breast tissue were investigated. Pretreatment of sections (enzymatic digestion, heating), endothelial markers (vWF-von Willebrand factor and CD31 antibodies), method of quantification (highest microvascular density, average microvascular density and microvascular volume) and inter-observer variations were all found to alter the estimated vascularity and interestingly the treatment of sections before staining was the variable that most significantly altered the calculated vascularity of tumours (Schor et al, 1998).

In order to overcome some of these problems an international consensus on the methodology and criteria for evaluation of IMD has been put forward (Vermeulen et al, 1996). The report proposes a standard method for IMD assessment and sets quality control standards aimed at improving reproducibility and intercentre comparability with regard to the selection of representative tissue samples, tissue processing and immunostaining, selection of areas for microvessel enumeration and the technique of vessel counting within these areas. A training programme for the inexperienced pathologist is also recommended given the subjective methodology of vascular hot spot selection and identification of individual microvessels. Few comparative studies have evaluated the different methods of microvessel quantification - manual counting. Chalkley count and CIAS. Further prospective studies are needed to define the method of choice. A standard technique for the evaluation of IMD would facilitate comparison between different centres and enable the organisation of confirmatory multicentre trials on the prognostic and predictive value of IMD in human solid tumours. 


\section{Endothelial cell specific antibodies}

Intra-tumoural microvessels can be identified by immunostaining of endothelial cells. Two categories of human endothelial cell specific antibodies are currently available: the pan-endothelial cell markers and antibodies that bind selectively to activated or proliferating endothelium (Table 1). The pan-endothelial markers are characterised by equal intensity of staining for small and large vessels and reactivity in both frozen and paraffin embedded samples. The latter feature is of clinical importance in that it facilitates their use on archival specimens. Generally, CD31 is utilised as the pan-endothelial marker of choice for paraffin sections. In a recent review (Fox et al, 2001), when studies on breast cancer with multivariate analysis that used antibodies to CD31 or CD34 were examined, most revealed a positive association with relapse free survival (RFS) (13 out of 14) and all for overall survival (OS) (12 out of 12). With studies using FVIII-RA, only eight out of 13 were positive for RFS and seven out of 10 for OS.

The problem of antigen specificity is highlighted by the detection of CD34 antigen on lymphatic vessels, perivascular stromal cells as well as other stromal elements while this is compounded by the absence of FVIII-RA on part of the capillary endothelium in tumour tissue (Holthofer et al, 1982; Parums et al, 1990; Traweek et al, 1991; Miettinen et al, 1994). The disadvantages associated with staining for CD31 antigen include co-staining of inflammatory cells, but these can be distinguished from endothelial cells on the basis of morphological differences, and frequent antigen loss due to fixatives that contain acetic acid (Vermeulen et al, 1996). Microwave antigen retrieval effectively abolishes this problem but in prospective studies a careful selection of the most suitable tissue fixation procedure should still be performed.

The ability to distinguish quantitatively between tumour neovascularisation and pre-existing vessels may be important in the assessment of tumour angiogenesis and could provide more accurate prognostic information. This is now possible using markers for activated endothelium. These markers are suitable for proliferating endothelium giving none or poor staining of lymphatics and normal quiescent blood vessels. They mainly react with fresh or frozen tissues, their activity in paraffin-embedded specimens is fixation dependent. In a study of 106 patients with breast carcinoma, the IMD was assessed using a pan-endothelial marker CD34 and a monoclonal antibody to CD105 that preferentially reacts with endothelial cells in angiogenic tissues. IMD values for CD105 expression showed a statistically significant correlation with RFS $(P=0.0362)$ and OS $(P=0.0029)$ in contrast to blood vessel counts using CD34 that did not correlate with RFS or OS (Kumar et al, 1999). This discrepancy in findings between the two markers could be the result of variability in the reactivity of different endothelial cell antibodies. While anti-CD105 antibody specifically reacts with endothelial cells of blood vessels in tissues undergoing angiogenesis, anti-CD34 antibody generally binds to endothelial cells in large blood vessels, although its expression can be diminished or restricted in some tumour microvessels (Wang et al, 1994). The superiority of the anti-CD105 antibody over antiCD34 was recently confirmed in another comparative study in 236 patients with NSCLC (Tanaka et al, 2001). CD105 determined IMD was a significant poor prognostic factor in multivariate analysis $(P=0.029)$ while CD34 determined IMD was not.

The activity of another marker for activated endothelium; LM609, a monoclonal antibody against integrin $\alpha_{\mathrm{v}} \beta_{3}$ has been investigated in a cohort of primary breast cancers and in normal breast tissue as control. LM609 preferentially immunostained proliferating blood vessels of small calibre within neoplastic tissue with weak expression of the integrin observed on vessels of normal tissue. In a series of 197 breast cancers, the expression of integrin $\alpha_{v} \beta_{3}$ at the vascular hot spot was the single most significant prognostic indicator for RFS in both node-negative and node-positive patients (Gasparini et al, 1998).

\section{The vascular hot spot}

Vascular hot spots are regions of high vascular density within the tumour and were first defined in breast cancer (Weidner et al, 1991). It was hypothesised that vascular hot spots arise from angio-

Table I Endothelial cell-specific antibodies: immunohistochemical characteristics

\begin{tabular}{|c|c|c|c|c|}
\hline \multirow[b]{2}{*}{ Antibody } & \multirow[b]{2}{*}{ Sensitivity } & \multirow[b]{2}{*}{ Specificity } & \multicolumn{2}{|c|}{ Reactivity } \\
\hline & & & Frozen & Paraffin \\
\hline Anti-CD3I & $\begin{array}{l}\text { Stain small and large vessels with } \\
\text { equal intensity }\end{array}$ & $\begin{array}{l}\text { Non-specific in cryostat sections - } \\
\text { occasional plasma cell staining in } \\
\text { formalin fixed tissue, no lymphatic } \\
\text { staining }\end{array}$ & Positive & Positive \\
\hline Anti-FVIII-RA & $\begin{array}{l}\text { Variable staining of large vessels and } \\
\text { capillaries, polyclonal antibody more } \\
\text { sensitive }\end{array}$ & $\begin{array}{l}\text { Monoclonal antibody more specific, } \\
\text { stromal staining with polyclonal } \\
\text { antibody }\end{array}$ & Positive & Positive \\
\hline Anti-Thrombomodulin & $\begin{array}{l}\text { Most sensitive for vascular tumours } \\
\text { e.g. angiosarcomas }\end{array}$ & Stains squamous epithelial cells & Positive & Negative \\
\hline Anti-CD34 & $\begin{array}{l}\text { Stains small and large vessels with } \\
\text { equal intensity in normal and tumour } \\
\text { tissue }\end{array}$ & $\begin{array}{l}\text { High, some lymphatic and perivascular } \\
\text { stromal staining }\end{array}$ & Positive & Positive \\
\hline E9 to CDI05 (activated) & $\begin{array}{l}\text { Small intra-tumoural vessels positive, } \\
\text { large vessels negative }\end{array}$ & Weak normal tissue vessel staining & Positive & $\begin{array}{l}\text { Positive } \\
\text { (fixation } \\
\text { dependent) }\end{array}$ \\
\hline $\begin{array}{l}\text { LM609 to integrin } \alpha_{v} \beta_{3} \\
\text { (activated) }\end{array}$ & $\begin{array}{l}\text { Preferentially stains small calibre blood } \\
\text { vessels in neoplastic tissue }\end{array}$ & $\begin{array}{l}\text { Weak expression in blood vessels of } \\
\text { normal tissues }\end{array}$ & Positive & $\begin{array}{l}\text { Positive } \\
\text { (fixation } \\
\text { dependent) }\end{array}$ \\
\hline $\begin{array}{l}\text { TEC-I I to endoglin } \\
\text { (activated) }\end{array}$ & $>80 \%$ of tumour vessels positive & $\begin{array}{l}\text { Eak staining of normal endothelial cells, } \\
\text { weak stromal staining }\end{array}$ & Positive & Negative \\
\hline
\end{tabular}

Adapted from Vermeulen et al (1996). Other endothelial markers in use are UEA-I, type IV collagenase, anti-CD36, PAL-E, BMAI20BW200, and EN-4. Other activated endothelial markers include EN7/44, 4AII, H4/18 and FB5. 
genic tumour cell clones and that these cells would predominantly enter the circulation and give rise to vascularised metastases. These areas are identified by an inspection of the tumour at low magnification. However, this is clearly time consuming when the diameter of some tumours often exceeds $10 \mathrm{~cm}$. It was suggested that the number of vascular hot spots analysed should be at least 10 to reduce the chances of missing the most vascular areas (Martin et al, 1995).

From the practical standpoint, assessment of IMD in selected areas compared to an overall vascular count is less time consuming. Vascular hot spots are encountered predominantly at the peripheral tumour margin and can be selected by scanning a tumour section at low magnification $(10-100 \times)$. A low background staining and highly specific and intense labelling of endothelial cells is required. Once the vascular hot spot is defined, a higher magnification is selected in order to be able to count individual microvessels. Magnifications of the order of $200-400 \times$ and field sizes ranging from 0.12 to $1.00 \mathrm{~mm}^{2}$ have been used (Vermeulen et al, 1996). A higher magnification improves the detail of the image and allows the identification of more single endothelial cell sprouts. An area larger or smaller than the vascular hot spot will result in loss of information.

According to an early study (Weidner et al, 1991), any highlighted endothelial cells or cell cluster clearly separate from adjacent microvessels, tumour cells and other connective tissue elements should be regarded as a distinct countable microvessel. This definition has several implications. Neither a lumen nor the presence of red blood cells is necessary to identify a microvessel. In addition a cut-off calibre size is not mentioned so that single cell sprouts as well as larger vessels are thus included in the counts. Even if distinct clusters give the impression of being part of one large vessel transfected by the plane of the tissue section more than once, they are counted as separate microvessels. Strict application of these objective criteria seems to result in lower inter-observer variability when analysing pre-defined hot spots.

Quantification of stained vessels can be achieved by measuring highest microvascular density (h-MVD), the average microvessel density (a-MVD) or the microvascular volume (MVV). The area of highest microvascular density (the vascular hot spot) is located by scanning the section at $100 \times$ magnification. In practice, localisation of the highest density area normally involves counting up to three different areas. Three different fields are counted in each of these areas at $200 \times$ magnification, and the highest value taken as the h-MVD, expressed as vessels per $\mathrm{mm}^{2}$. The a-MVD is determined using the same grid and magnification $(200 \times)$ as for hMVD and calculating the mean of the vascular counts obtained in at least 10-15 random fields for each tissue section. Results for a-MVD are expressed as mean \pm standard deviation (vessels per $\mathrm{mm}^{2}$ ) (Schor et al, 1998). The MVV is estimated by point counting using an eyepiece graticule, which contains 100 points. Vessels that coincide with the points are counted in 15 fields selected randomly across each section (a total of 1500 points) and yields results expressed as percentage volume.

The Chalkley method resembles that used to determine the MVV. Tumour sections are scanned at low magnification to identify the areas that appear to have the maximum number of discrete microvessels. At higher magnifications, an eyepiece graticule containing 25 randomly positioned dots is rotated so that the maximum numbers of points are on or within the vessels of the vascular hot spot. Instead of counting the individual microvessels, the overlying dots are counted. In a series of patients with breast carcinoma (Fox et al, 1995), a significant correlation was found between MVD assessment by the Weidner method and Chalkley point counting ( $r=0.7, P=0.00005)$. A significant reduction in OS was observed between patients stratified by Chalkley count in both univariate $(P=0.02)$ and multivariate analysis $(P=0.05)$. In another study in patients with node-positive breast carcinoma, Chalkley score was found to be the most significant independent predictor of outcome by multivariate analysis (Gasparini et al, 1996). In a series of 330 breast cancers (Rose et al, 2000), Chalkley count was compared to manual microvessel counting and provided independent prognostic value in multivariate analysis $(P<0.0001$ for RFS, $P=0.001$ for OS). Manual microvessel counting had no prognostic impact. In another study of 104 malignant mesotheliomas, IMD as assessed by Chalkley counting was assessed with respect to other known prognostic factors in malignant mesothelioma. Chalkley microvessel count was shown to be an independent prognostic factor in multivariate analysis $(P=0.006)$ (Edwards et al, 2001). Since no decisions have to be made on whether adjacent stained structures are stained microvessels or not, Chalkley point counting should be a more objective approach.

The first problem that arises with the quantification techniques is the selection of a representative tumour block. In colorectal adenocarcinoma, the IMD in in-situ growth regions is approximately half of that seen in invasive regions (Vermeulen et al, 1995) suggesting that multiple blocks should be assessed. de Jong et al (1995) found a higher average coefficient of variation $(24 \%)$ if more than one tissue block was analysed compared to a lower coefficient of variation (15\%) when only counts within sections of one block were examined, indicating that a comprehensive inspection of available tumour material is needed to identify the relevant hot spots.

The training and experience of the investigator influences the identification of the vascular hot spot. Barbareschi et al (1995) compared the calculated IMD in 91 node negative invasive breast carcinomas by light microscopy when measured by two pathologists of different experience. Both at univariate and multivariate analysis, only the counts of the experienced pathologist were significantly associated with relapse-free survival. Similar results were noted in another series of node negative breast cancer patients (Vermeulen et al, 1997). Once the vascular hot spot is identified, vessel counts after agreement on the description of a single countable vessel appears to be less dependent on subjective interpretation than the process of hot spot selection.

\section{Grading of IMD}

In addition to the vascular hot spot technique another method is semiquantitative grading. Several studies have reported a positive correlation between quantitative and semiquantitative MVD scores. Weidner et al (1991) subjectively graded angiogenesis in vascular hot spots and counted individual microvessels in the same fields (Weidner et al, 1992). MVD values obtained by both methods were a statistically significant predictor of RFS and OS. The obvious advantage of IMD grading is its time efficiency. However, translation of a continuum of MVD values into a categorical type of data will however be associated with some loss of information. Given the highly subjective nature of IMD grading, comparable results will only be obtained by different observers after a period of training with standardised methods.

\section{Computerised Image Analysis systems (CIAS)}

This is an automated counting technique that improves reproducibility and reduces inter-observer variability and has been proposed as a more objective method of assessing IMD (Wakui et al, 1992; Visscher et al, 1993). In a series of 91 node-negative invasive ductal carcinomas of the breast, both the number of CD31 positive microvessels measured by an experienced observer and the microvessel area (MVA) determined by CIAS were independently associated with RFS (Barbareschi et al, 1995). Fox et al (1995) also reported comparable results in another series of patients with breast carcinoma.

The main advantage of CIAS is the additional morphometric parameters that can be detected i.e. the number of vessels with a certain dimension range, the vessel luminal area, vessel luminal 
perimeter and the number of immunostained areas per microscopic field. IMD can be measured more objectively without the intervention of an investigator. The apparent disadvantage of CIAS is the time consuming nature of the method and its higher cost. These systems are not fully automated yet and require a high degree of operator interaction. The vascular hot spot is still identified manually before automated counting as the heterogeneity of microvessel morphology and immunostaining intensity particularly hampers a fully automated analysis of tumour IMD.

\section{IMD AND METASTASIS}

As tumour metastasis is the major cause of mortality in cancer patients, a classification of the metastatic potential of a tumour could be of great clinical significance. A quantitative relationship between IMD, the number of intravascular tumour cells and the occurrence of pulmonary metastasis was shown in an animal tumour model more than 20 years ago (Liotta et al, 1974) but clinical confirmation has only been revealed in the last few years (McCulloch et al, 1995). Before surgery for patients with primary breast cancer, a central venous catheter was fixed in the ipsilateral subclavian vein. Blood samples were taken before, during and 1 day after surgery and tumour cells were identified on the basis of cytokeratin positivity. Microvessels were highlighted with anti-CD34 antibody in tissue sections of the invasive tumour component and the IMD was measured in the vascular hot spots. The majority of patients with a high vascular density had cells detected during operation in contrast to a minority of patients with a low IMD, suggesting that the frequency of tumour cell shedding was related to $\operatorname{IMD}(r=0.56, P=0.024)$.

Evidence that the intensity of angiogenesis in a human tumour could predict the probability of metastasis was initially reported in cutaneous melanoma (Srivastava et al, 1986, 1988). There was a clear distinction between a stage without neovascularisation, which correlated with a low rate of metastasis, and a stage in which increasing neovascularisation correlated with an increased rate of local and distant metastasis $(P=0.025)$. Weidner et al (1991), in one of the earliest studies, reported a significant correlation between the degrees of IMD at the vascular hot spot with the probability of metastasis in a series of 49 patients with invasive breast cancer. Using light microscopy, blood vessels were highlighted by staining their endothelial cells immunocytochemically for factor VIII. The microvessels were counted (per $200 \times$ field), and their density graded $(1-4+)$ in the most active areas of neovascularisation. Both microvessel counts and density grades were found to correlate with metastatic disease. For each 10-microvessel increase in the vessel count per $200 \times$ field, there was a 1.17 -fold increase in the risk of distant metastasis $(P=0.029)$. In another series of patients with node-negative breast cancer, assessment of IMD by immunohistochemistry with anti-CD31 antibody, IMD correlated significantly with recurrence in viscera, bone and soft tissue deposits (Gasparini et al, 1994). Several studies have now shown that highly vascularised tumours have a significantly higher likelihood to present with loco-regional lymph node metastasis than those that are poorly vascularised. Likewise a similar correlation between IMD in the primary tumour and the development of distant metastasis was found (Table 2).

The expression levels of genes that regulate metastasis and angiogenesis can predict metastatic potential in individual patients. This was demonstrated in a study of 46 renal cancers (Slaton et al, 2001). The expression levels of basic fibroblast growth factor, vascular endothelial growth factor, interleukin-8 (IL-8), matrix metalloproteinases (MMP) 2 and 9 and E-cadherin were examined at the periphery of the tumour by a colorimetric in situ mRNA.

Table 2 Clinicopathological studies of IMD and metastasis

\begin{tabular}{|c|c|c|c|c|c|}
\hline \multirow[b]{2}{*}{ Author } & \multirow{2}{*}{$\begin{array}{l}\text { Endothelial } \\
\text { marker }\end{array}$} & \multirow{2}{*}{$\begin{array}{l}\text { Tumour } \\
\text { type }\end{array}$} & \multirow{2}{*}{$\begin{array}{l}\text { Number of } \\
\text { patients }\end{array}$} & \multicolumn{2}{|c|}{ Association with metastasis } \\
\hline & & & & Nodal $P$ & Distant $P$ \\
\hline Weidner et al (|99|) & FVIII-RA & Breast & 49 & 0.003 & 0.003 \\
\hline Hall et al (1992) & FVIII-RA & Breast & 87 & NS & NS \\
\hline Ogawa et al (1995) & FVIII-RA & Breast & 155 & No correlation & ND \\
\hline Fox et al (1997b) & CD-31 & Breast & 214 & NS & 0.01 \\
\hline Arapandoni-Dadioti et al (1999) & CD31 & Breast & 35 & 0.006 & ND \\
\hline Hansen et al (2000) & CD-34 & Breast & 836 & NS & 0.01 \\
\hline Elpek et al (200I) & CD34 & Oesophagus & 53 & $<0.05$ & ND \\
\hline Maeda et al (1995) & FVIII-RA & Gastric & 124 & $<0.01$ & NS \\
\hline Tanigawa et al (1997) & CD-34 & Gastric & 181 & 0.11 & 0.0001 \\
\hline Xiangming et al (1998) & FVIII-RA & Gastric & 97 & 0.0016 & ND \\
\hline Oh-e et al (200I) & CD34 & Colon & 254 & 0.0026 & ND \\
\hline Vermeulen et al (1999) & CD34 & Colon & 145 & NS & 0.001 \\
\hline Gasparini et al (1995b) & $C D-31$ & Head and neck SCC & 70 & 0.004 & 0.004 \\
\hline Lane et al (1997) & UEA-I & Uveal melanoma & 63 & ND & NS \\
\hline Macchiarini et al (1992) & FVIII-RA & NSCLC & 87 & $<0.0001$ & $<0.0001$ \\
\hline Fontanini et al (1995) & FVIII-RA & NSCLC & 253 & $<0.00000 \mid$ & $\begin{array}{c}0.01 \\
\text { (dichotomous } \\
\text { variable) } \\
P=0.003 \\
\text { (continuous } \\
\text { variable) }\end{array}$ \\
\hline Weidner et al (1993) & FVIII-RA & Prostate & 74 & ND & $\begin{array}{c}<0.000 \mathrm{I} \\
\text { (bone marrow } \\
\text { mets only) }\end{array}$ \\
\hline Halvorsen et al (2000) & FVIII-RA & Prostate & 104 & $\begin{array}{c}0.0084 \\
\text { (clinical recurrence) }\end{array}$ & ND \\
\hline Olivarez et al (1994) & FVIII-RA & $\begin{array}{l}\text { Testicular germ cell } \\
\text { tumour }\end{array}$ & 65 & 0.011 & ND \\
\hline Fukuda et al (1999) & FVIII-RA & $\begin{array}{l}\text { Testicular germ cell } \\
\text { tumours }\end{array}$ & 80 & ND & $P<0.00$ \\
\hline
\end{tabular}

ND, not done; NS, not significant. 
The expression levels of bFGF, VEGF, IL-8, MMP 2 and 9 were significantly higher in primary renal tumours from patients with synchronous or metachronous metastases than those who were disease free at a median of 48 months of follow up. Multivariate analysis of RFS showed that the ratio of MMP-9 to E-Cadherin $(P=0.012)$ and the expression level of bFGF expression $(P=0.045)$ were independent predictors for the development of metastases.

The expectation that determination of an angiogenic index by IMD can identify all patients with occult metastatic disease or those with probable distant metastasis is probably unrealistic. Human tumours are heterogeneous and consist of subpopulations of cells with different biological properties. Secondly, the process of development of metastasis consists of a series of interlinked independent steps. To produce clinically relevant metastasis, tumour cells must complete all the steps in this process. Tumour cells that can induce intense angiogenesis but cannot survive in the circulation or proliferate in distant organs will not produce metastasis (Ellis and Fidler, 1996). Like the other steps in the metastatic cascade, angiogenesis is necessary but not sufficient for the pathogenesis of metastasis.

\section{IMD AS A PREDICTIVE MARKER OF RESPONSE TO ANTI-CANCER THERAPY}

Although IMD has been shown to correlate with metastasis and survival one might anticipate that the increased vascularity may improve tumour oxygenation and drug delivery thereby improving the response to therapy. However, the converse has generally been reported (Table 3 ). In a study of patients with squamous cell carcinoma of the head and neck treated with concurrent chemoradiation, the degree of IMD was significantly predictive of poor response to platinum-based chemotherapy in terms of complete response $(P=0.045)$ (Gasparini et al, 1995b). Similar find- ings have been observed in patients with epithelial ovarian cancers treated with platinum-based combination chemotherapy (Hollingsworth et al, 1995).

If patients present with highly angiogenic primary tumours and these are the patients most likely to develop distant recurrences, then it might follow that this group of patients are most likely to benefit from adjuvant therapy. However in contrast to this hypothesis, the above studies demonstrate that angiogenic tumours have a more aggressive phenotype and do not benefit as anticipated. Perhaps tumours of low angiogenic index are more likely to benefit from adjuvant therapy even though they are also the subgroup of patients least likely to develop a recurrence. Perhaps patients with highly angiogenic tumours should therefore be selected for trials that include the use of anti-angiogenic strategies. The general observation from the above data is thus that the greater the degree of vascularisation in a solid tumour, the lower the likelihood of responsiveness to conventional anti-cancer therapy although this conclusion needs further evaluation in well-designed prospective studies.

\section{IMD AND PROGNOSIS}

If IMD is associated with metastasis then it is logical to predict that IMD will also be associated with survival and this has been evaluated in most solid tumours including breast, ovary, bladder, head and neck and prostate cancers amongst others (Tables 4 and 5). Two pivotal independent studies by Horak et al (1992) and Weidner et al (1992) found that IMD is a significant and independent prognostic factor in human invasive breast cancer. In a prospective blinded study of 165 patients with breast cancer, Weidner and Folkman showed that there was a highly significant association between IMD and RFS and OS in both node-negative and nodepositive subsets $(P=0.01)$. All patients with breast carcinomas

Table 3 IMD and prediction of efficacy of anti-cancer therapy

\begin{tabular}{|c|c|c|c|c|c|}
\hline $\begin{array}{l}\text { Author } \\
\text { (year) }\end{array}$ & $\begin{array}{l}\text { Endothelial } \\
\text { marker }\end{array}$ & $\begin{array}{l}\text { Tumour } \\
\text { type }\end{array}$ & $\begin{array}{l}\text { Number of } \\
\text { patients }\end{array}$ & Treatment & $\begin{array}{l}\text { Prediction of } \\
\text { efficacy ( } P \text { value) }\end{array}$ \\
\hline Weidner et al (1992) & FVIII-RA & Breast & 82 & $\begin{array}{l}\text { Heterogeneous } \\
\text { adjuvant treatments }\end{array}$ & $\begin{array}{l}\text { Yes }(P<0.00 \text { I for RFS } \\
\text { and } O S)\end{array}$ \\
\hline Gasparini et al (1993) & FVIII-RA & Breast & 42 & $\begin{array}{l}\text { Neoadjuvant or palliative } \\
\text { chemotherapy }\end{array}$ & No \\
\hline Gasparini et al (1995a) & CD-3I & Breast & 191 & $\begin{array}{l}\text { Adjuvant chemotherapy or } \\
\text { endocrine therapy }\end{array}$ & $\begin{array}{l}\text { Yes }(P<0.01 \text { for RFS } \\
\text { and } O S)\end{array}$ \\
\hline Toi et al (1995b) & FVIII-RA & Breast & 198 & $\begin{array}{l}\text { Heterogeneous adjuvant } \\
\text { treatments }\end{array}$ & Yes $(P<0.05$ for RFS $)$ \\
\hline Macaulay et al (1995) & CD-3I & Breast & 88 & Adjuvant tamoxifen & $\begin{array}{l}\text { Yes for RFS in ER } \\
\text { positive cases, } \\
P=0.022 \text { ) }\end{array}$ \\
\hline Gasparini et al (1996) & CD-3I & Breast & 178 & Adjuvant tamoxifen & $\begin{array}{l}\text { Yes }(P<0.01 \text { for RFS } \\
\text { and } O S)\end{array}$ \\
\hline Vacca et al (1994) & FVIII-RA & Multiple myeloma & 46 & Various schedules & $\begin{array}{l}\text { Yes (active vs no active disease } \\
\text { response } P=0.045 \text { ) }\end{array}$ \\
\hline Gasparini et al (1995b) & CD-3I & Head and neck SCC & 73 & $\begin{array}{l}\text { Concurrent } \\
\text { chemoradiotherapy }\end{array}$ & $\begin{array}{l}\text { Yes (CR vs no response } \\
P=0.045)\end{array}$ \\
\hline Aebersold et al (2000) & CD-3I & Oropharynx & 139 & XRT & Yes $(P=0.000 \mid$ for RFS $)$ \\
\hline Kamijo et al (2000) & CD-3I & Larynx & 31 & XRT & $\begin{array}{l}\text { Yes (for radiosensitivity } \\
P=0.008\end{array}$ \\
\hline Hollingsworth et al (1995) & CD-34 & Ovary & 43 & $\begin{array}{l}\text { Platinum-based } \\
\text { chemotherapy }\end{array}$ & $\begin{array}{l}\text { Yes }(P=0.064 \text { for } O S \\
P=0.0036 \text { for RFS })\end{array}$ \\
\hline Van Diest et al (1995) & $\begin{array}{l}\text { Lectin-Ulex } \\
\text { europaeus-I }\end{array}$ & Ovary & 49 & $\begin{array}{l}\text { Platinum-based } \\
\text { chemotherapy }\end{array}$ & $\begin{array}{l}\text { No (only a trend for } \\
\text { worse OS) }\end{array}$ \\
\hline Gasparini et al (1998) & CD-3I & Ovary & 60 & $\begin{array}{l}\text { Platinum-based } \\
\text { chemotherapy }\end{array}$ & $\begin{array}{l}\text { Yes }(P<0.0 \text { I for poor } \\
\text { response) }\end{array}$ \\
\hline Cooper et al (1998) & FVIII-RA & Cervix & || $\mid$ & XRT & Yes for OS $(P=0.04 \mathrm{I})$ \\
\hline Cooper et al (1999) & FVIII-RA & Cervix & 74 & XRT & $\begin{array}{l}\text { No correlation between } \\
\text { IMD and intrinsic } \\
\text { radiosensitivity }\end{array}$ \\
\hline
\end{tabular}


Table 4 IMD and prognosis in breast cancer

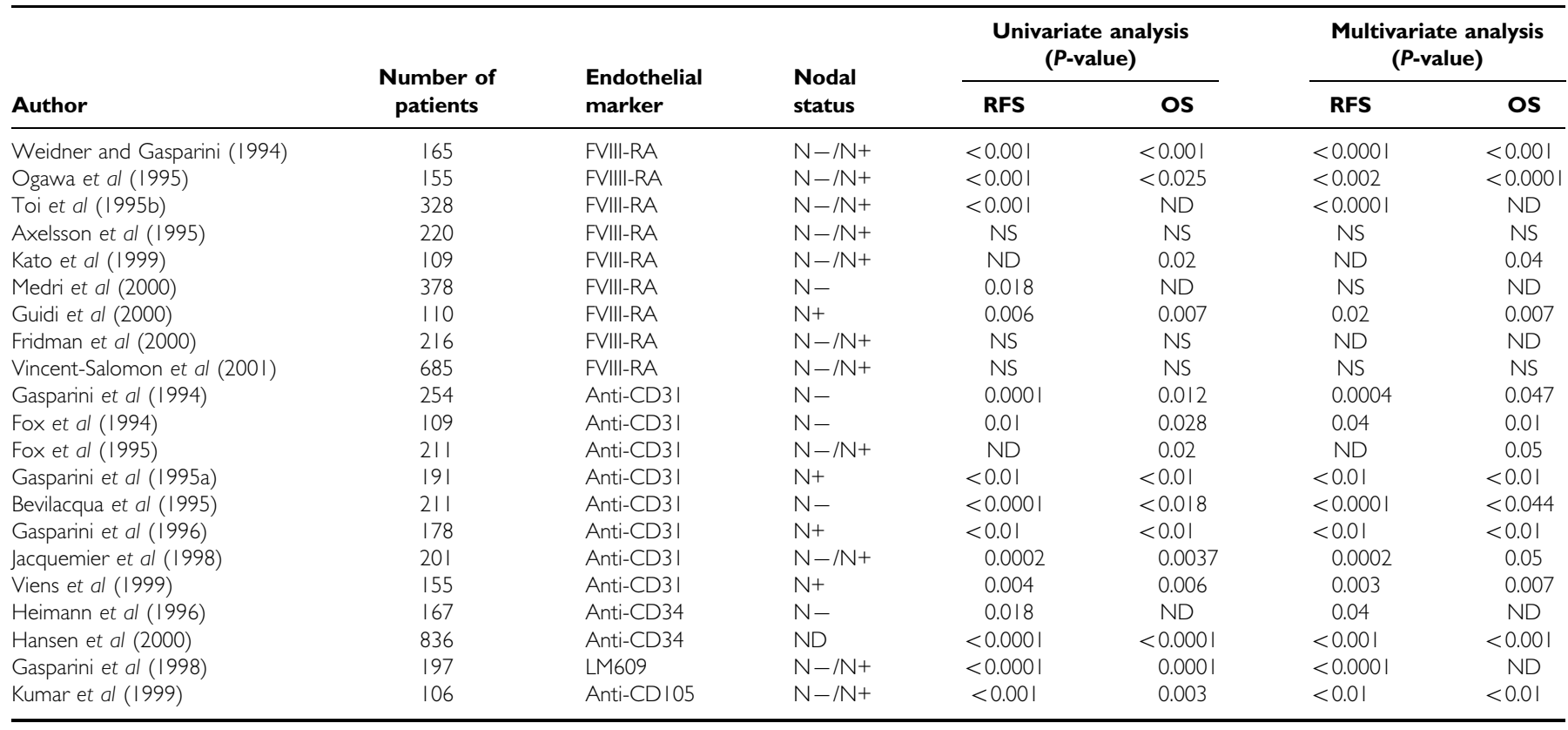

Table 5 Studies on IMD and prognosis in solid tumours

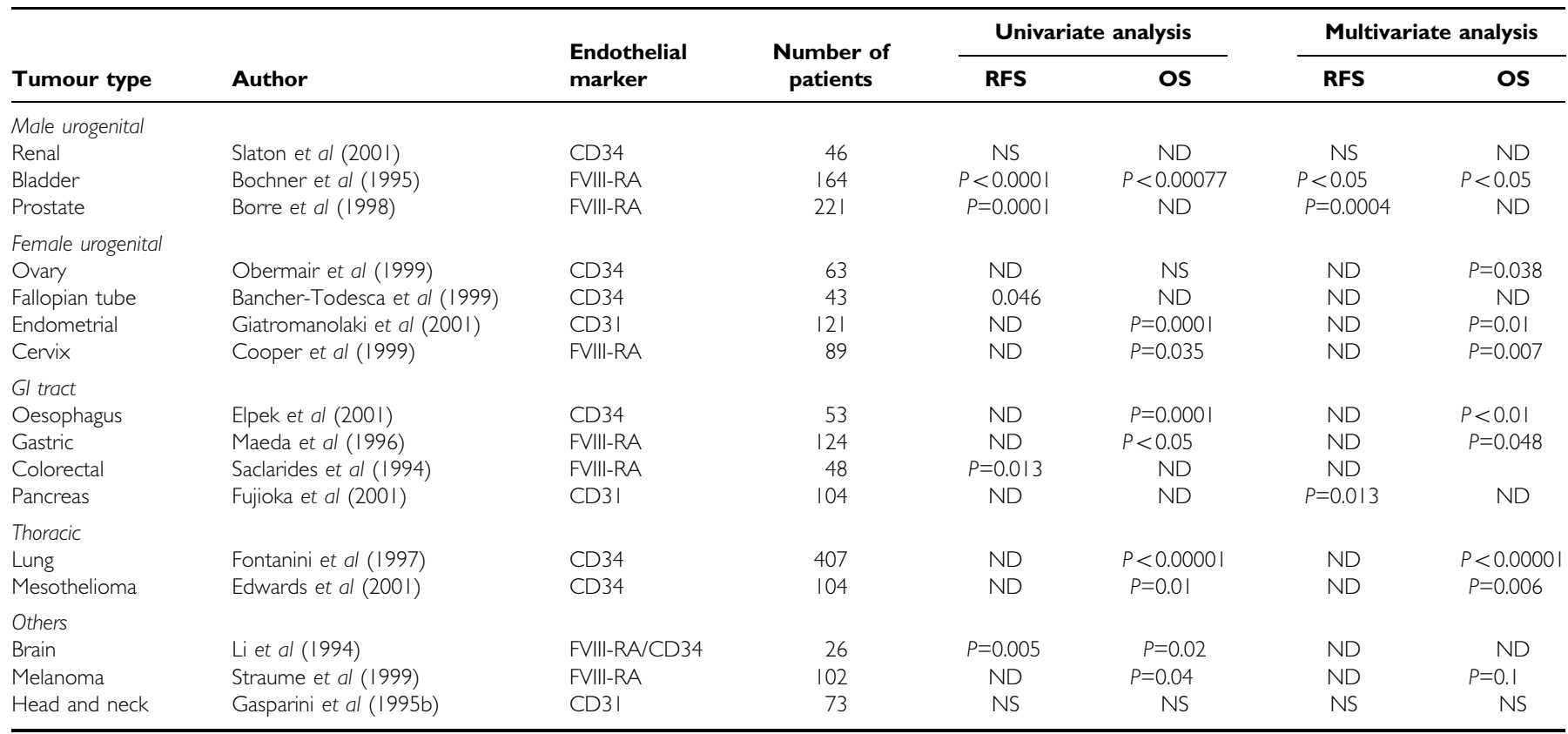

containing more than 100 microvessels per $200 \times$ field experienced tumour recurrence within 33 months of diagnosis, compared with less than $5 \%$ of patients with breast cancer having 33 or fewer microvessels per $200 \times$ field. Moreover IMD was the only statistically significant predictor of $O S$ in node-negative patients $(P<0.001)$. In the study by Horak et al $(1992)$ microvessels were counted in 103 patients with primary breast cancer using the JC70 antibody to CD31. Tumours showed significantly higher vascularisation than normal breast tissue and the number of blood vessels $/ \mathrm{mm}^{2}$ was significantly associated with node metastasis $(P<0.00001)$. Vascularity was correlated with the size of the primary tumour and with poor differentiation. Within each subgroup of size or differentiation, tumours without nodal involvement had much lower IMD. Even with the short follow up in this study, high vascular counts correlated with early deaths.

Over a hundred retrospective studies have been published on the prognostic significance of IMD in solid tumours. In breast cancer alone more than 40 retrospective studies have been published with more than 7000 patients evaluated. Since these patients have different pathological and clinical characteristics, a proper metaanalysis is not possible. Nevertheless more than $75 \%$ of studies reported positive results on the association of IMD with clinical outcome 
and more than $85 \%$ of the 27 studies, which included multivariate analysis, found that IMD was an independent prognostic variable (Gasparini and Harris, 1995; Ellis et al, 1998; Gasparini, 2001) and these findings have been observed in both the adjuvant and metastatic disease settings (Gasparini et al, 1995a, 1996; Macaulay et al, 1995; Toi et al, 1995b). The bulk of accumulating data indicates that IMD in the area of most intense neovascularisation in invasive breast cancer is an independent, significant and accurate prognostic marker in predicting poorer survival. Such an indicator might be potentially useful in tailoring adjuvant therapy for highrisk breast cancer patients although there is no data at present linking aggressive treatment to better outcome in such patients. Clearly prospective evaluation of this area is required.

The prognostic value of IMD has been studied in other solid tumours apart from breast cancer. These include cancers of the lung, genito-urinary tract, GI tract, head and neck, gynaecological malignancies and malignant melanomas. In the largest single series, IMD was assessed prospectively in 407 patients with stages I-III non-small cell lung cancer (NSCLC). Anti-CD34 antibody was used to measure angiogenesis in tumour samples. In multivariate analysis IMD, tumour microvessel count $(P<0.00001)$, tumour size and regional lymph node status retained independent prognostic value with respect to overall survival. Among these variables, tumour microvessel count considered as a continuous variable was the most important (Fontanini et al, 1997).

\section{Poor associations between IMD and survival}

There are several reports that do not demonstrate a relationship between IMD and survival (Hall et al, 1992; van Hoef et al, 1993; Axelsson et al, 1995; Costello et al, 1995; Goulding et al, 1995; Morphopoulos et al, 1996). While these studies may reflect a genuine biological finding there are a number of technical issues that may confound studies. For instance a discrepancy may be related to potential methodological pitfalls in case selection, small study populations, heterogeneous therapy, inadequate follow-up and statistical analysis. Issues related to the application of immunohistochemical techniques including choice of endothelial marker, the vascular variable quantified and the area of tumour section assessed and inter-observer variability could also contribute. On the other hand, the tendency for positive results to be published may have led to an exaggerated assessment of the importance of IMD.

It is possible that some tumours are less angiogenesis-dependent than others. For example, in intestinal-type gastric cancer, vessel counts correlate with stage of disease and metastasis formation (Takahashi et al, 1996). In contrast vessel counts in diffuse-type gastric cancer do not correlate with metastasis and in general vessel counts in diffuse-type gastric cancer are lower those seen in intestinal-type gastric cancer.

Tumours may also be able to grow without neovascularisation if a suitable vascular bed is available. The pattern of vascularisation was studied in 500 cases of non-small cell lung cancer. Of these $80(16 \%)$ were characterised by an absence of stroma and lack of new vessel formation (Pezzella et al, 1997). In such cancers, the degree of neovascularisation as assessed by IMD may not be of prognostic value. On the other hand, in colon cancer, the presence of ulceration and adjacent inflammation may itself contribute to increased local vascularity independent of the tumour and may confound results (Abdalla et al, 1999). Discordant results from studies may also reflect the fact that angiogenesis is but one step in the multistep process of metastasis. If a primary tumour has a high angiogenic index, but does not express other factors necessary for metastasis formation (i.e. adhesion/cohesion molecules, motility factors, growth factor receptors, etc.), then despite the high degree of angiogenesis, metastasis will not occur.

A further mechanism by which the discrepancy between IMD and survival may occur is vasculogenic mimicry, which has been described in melanoma. In aggressive primary and metastatic melanomas, the tumour cells generate microcirculatory channels composed of extracellular matrix that are lined by tumour cells (Maniotis et al, 1999; Folberg et al, 2000). The channels generated through this process by tumour cells may not stain with endothelial cell markers, as endothelial cells are not present.

Despite the fact that the overall trend in most studies is that the assessment of IMD retains a prognostic value in the majority of solid tumours, no definitive conclusions can be drawn at present on the real clinical usefulness of this approach. Before adopting IMD as a prognostic marker in routine clinical application, appropriate prospective trials are needed to validate the results observed in retrospective studies. Furthermore the method of assessment of IMD is inconsistent and needs to be standardised and made more objective.

\section{CONCLUSION}

There is sufficient evidence to justify the determination of IMD as a measure of the angiogenic activity of human solid tumours. This method may be improved by employing more selective and specific markers for activated/proliferating endothelium, improving staining techniques, using more objective and reproducible methods for microvessel counting and standardisation of the criteria for evaluation of IMD and of the identification of the neovascular hot spot within each tumour.

As alternative methods like serum and tissue sampling of angiogenic peptides, measurement of endothelial cell proliferation, cell adhesion molecules and proteolytic enzymes as well as dynamic contrast enhanced MRI become available, these may enhance the accuracy of the measurement of angiogenic activity in solid tumours.

A strong correlation has been confirmed between the IMD of a primary tumour and its potential to develop locoregional or distant metastasis. Assessment of tumour vascularity is now an established prognostic indicator in early stage breast cancer, NSCLC and prostatic carcinoma (Gasparini and Harris, 1999). In these tumour types, the majority of retrospective studies found a significant correlation between vascularisation of the primary tumour and clinical outcome of patients. In other tumour types the role of IMD remains investigational and requires well-designed prospective studies. Preliminary studies suggest that the determination of angiogenesis may serve as a marker to predict response to some forms of conventional anti-cancer therapy. An inverse relationship between the degree of vascularisation and responsiveness to anticancer therapy has been shown in the adjuvant setting as well as for advanced tumours.

Certain issues remain unresolved. Besides the technical standardisation issues, it is unclear whether antibodies directed against activated endothelium will predict metastasis and survival better than other pan-endothelial methods. This issue needs to be addressed in a large study before we can establish prospective trials that are ultimately needed to validate IMD as a guide to therapy. 


\section{REFERENCES}

Abdalla SA, Behzad F, Bsharah S, Kumar S, Amini SK, O’Dwyer ST, Haboubi NY (1999) Prognostic relevance of microvessel density in colorectal tumours. Oncol Rep 6: 839-842

Aebersold DM, Beer KT, Laissue J, Hug S, Kollar A, Greiner RH, Djonov V (2000) Intratumoral microvessel density predicts local treatment failure of radically irradiated squamous cell carcinoma of the oropharynx. Int Radiat Oncol Biol Phys 48: 17-25

Anderson H, Price P, Blomley M, Leach MO, Workman P (2001) Measuring changes in human tumour vasculature in response to therapy using functional imaging techniques. Br J Cancer 85: 1085-1093

Arapandoni-Dadioti P, Giatromanolaki A, Trihia A, Harris AL, Koukourakis MI (1999) Angiogenesis in ductal breast carcinoma. Comparison of microvessel density between primary tumour and lymph node metastasis. Cancer Lett 137: $145-150$

Axelsson K, Ljung BM, Moore 2nd DH, Thor AD, Chew KL, Edgerton SM, Smith HS, Mayall BH (1995) Tumour angiogenesis as a prognostic assay for invasive ductal breast carcinoma. J Natl Cancer Inst 87: 997- 1008

Bancher-Todesca D, Rosen A, Graf A, Wasicky R, Hohlagschwandtmer M, Rebhandl W, Heinze G, Breiteneck G, Gitsch G, Obermair A (1999) Prognostic significance of tumour angiogenesis in primary fallopian tube cancer. Cancer Lett 141: 179-186

Barbareschi M, Weidner N, Gasparini G, Morelli L, Forti S, Eccher C, Fina P, Mauri F, Bevilacqua P, Dalla Palma P (1995) Microvessel density quantification in breast carcinomas. Assessment by light microscopy versus a computer aided image analysis system. Appl Immunohistochem 3: 75-84

Bevilacqua P, Barbareschi M, Verderio P, Boracchi P, Caffo O, Dalla Palma P, Meli S, Weidner N, Gasparini G (1995) Prognostic value of intratumoral microvessel density, a measure of tumour angiogenesis, in node-negative breast carcinoma. Results of a multiparametric study. Breast Cancer Res Treat 36: $205-217$

Bochner BH, Cote RJ, Weidner N, Groshen S, Chen SC, Skinner DG, Nichols PW (1995) Angiogenesis in bladder cancer: relationship between microvessel density and tumour prognosis. J Natl Cancer Inst 87: 1603-1612

Borre M, Offersen BV, Nerstrom B, Overgaard J (1998) Microvessel density predicts survival in prostate cancer patients subjected to watchful waiting. Br J Cancer 78: $940-944$

Brasch RC, Li KC, Husband JE, Keogan MT, Neeman M, Padhani AR Shames D, Turetschek K (2000) In vivo monitoring of tumour angiogenesis with MR imaging. Acad Radiol 7: 812-823

Brasch R, Turetschek K (2000) MRI characterization of tumours and grading angiogenesis using macromolecular contrast media: status report. Eur $J$ Radiol 34: $148-155$

Brown NS, Bickness R (1998) Thymidine phosphorylase, 2-deoxy-D-ribose and angiogenesis. Biochem J 334: 1-8 (Review)

Burian M, Quint C, Neuchrist C (1999) Angiogenic factors in laryngeal carcinomas: do they have prognostic relevance?. Acta Otolaryngol 119: 289-292

Cheng WF, Lee CN, Chu JS, Chen CA, Chen TM, Shau WY, Hsieh FJ (1999) Vascularity index as a novel parameter for the in vivo assessment of angiogenesis in patients with cervical carcinoma. Cancer 85: 651-657

Cooper RA, Wilks DP, Logue JP, Davidson SE, Hunter RD, Roberts SA, West CM (1998) High tumour angiogenesis is associated with poorer survival in carcinoma of the cervix treated with radiotherapy. Clin Cancer Res 4: $2795-2800$

Cooper RA, West CM, Wilks DP, Logue JP, Davidson SE, Roberts SA, Hunter RD (1999) Tumour vascularity is a significant prognostic factor for cervix carcinoma treated with radiotherapy: independence from tumour radiosensitivity. Br J Cancer 81: 354-358

Cooper RA, Carrington BM, Loncaster JA, Todd SM, Davidson SE, Logue JP, Luthra AD, Jones AP, Stratford I, Hunter RD, West CM (2000) Tumou oxygenation levels correlate with dynamic contrast-enhanced magnetic resonance imaging parameters in carcinoma of the cervix. Radiother Oncol 57: $53-59$

Costello P, McCann A, Carney DN, Dervan PA (1995) Prognostic significance of microvessel density in lymph node negative breast cancer. Hum Pathol 26: $181-184$

de Jong JS, van Diest PJ, Baak JP (1995) Heterogeneity and reproducibility of microvessel counts in breast cancer. Lab Invest 73: $992-996$

Delorme S, Knopp MV (1998) Non-invasive vascular imaging: assessing tumour vascularity. Eur Radiol 8: 517-527

Edwards JG, Cox G, Andi A, Jones JL, Walker RA, Waller DA, O’Byrne KJ (2001) Angiogenesis is an independent prognostic factor in malignant mesothelioma. Br J Cancer 85: 863-868
Ellis LM, Fidler IJ (1996) Angiogenesis and metastasis. Eur J Cancer32A: $2451-2460$

Ellis LM, Walker RA, Gasparini G (1998) Is determination of angiogenic activity in human tumours clinically useful?. Eur J Cancer34 609-618

Elpek GO, Gelen T, Aksoy NH, Erdogan A, Dertsiz L, Denircan A, Keles N (2001) The prognostic relevance of angiogenesis and mast cells in squamous cell carcinoma of the oesophagus. J Clin Pathol 54: 940-944

Fanelli M, Locopo N, Gattuso D, Gasparini G (1999) Assessment of tumour vascularisation: immunohistochemical and non-invasive methods. Int $J$ Biol Markers 14: $218-231$

Folberg R, Hendrix MJ, Maniotis AJ (2000) Vasculogenic mimicry and tumour angiogenesis. Review. Am J Pathol 156: $361-381$

Folkman J (1972) Anti angiogenesis: new concept for therapy of solid tumours. Ann Surg 175: 409-416

Folkman J (1996) What is the role of thymidine phosphorylase in tumour angiogenesis? J Natl Cancer Inst 73: 275-280

Fontanini G, Bigini D, Vignati S, Basalo F, Mussi A, Lucchi M, Chine S, Angeletti CA, Harris AL, Bevilacqua G (1995) Microvessel count predicts metastatic disease and survival in non-small cell lung cancer. J Pathol 177: $57-63$

Fontanini G, Lucchi M, Vignati S, Mussi A, Ciardiello F, De Laurentiis M, De Placido S, Basolo F, Angeletti CA, Bevilacqua P (1997) Angiogenesis as a prognostic indicator of survival in non-small cell lung carcinoma: a prospective study. J Natl Cancer Inst 89: $881-886$

Fox SB, Leek RD, Smith K, Hollyer J, Greenall M, Harris AL (1994) Tumour angiogenesis in node-negative breast carcinomas-relationship with epidermal growth factor receptor, oestrogen receptor and survival. Breast Cancer Res Treat 29: 109-116

Fox SB, Leek RD, Weekes MP, Whitehouse RM, Gatter KC, Harris AL (1995) Quantitation and prognostic value of breast cancer angiogenesis: Comparison of microvessel density, Chalkley count and computer image analysis. $J$ Pathol 177: 275-283

Fox SB, Westwood M, Moghaddam A, Comley M, Turley H, Whitehouse RM, Bicknell R, Gatter KC, Harris AL (1996) The angiogenic factor platelet-derived endothelial cell growth factor/thymidine phosphorylase is upregulated in breast cancer epithelium and endothelium. Br J Cancer 73: $275-280$

Fox SB, Engels K, Comley M, Whitehouse RM, Turley H, Gatter KC, Harris AL (1997a) Relationship of elevated tumour thymidine phosphorylase in node-positive breast carcinomas to the effects of adjuvant CMF. Ann Oncol 8: $271-275$

Fox SB, Leek RD, Bliss J, Mansi JL, Gusterson B, Gatter KC, Harris AL (1997b) Association of tumour angiogenesis with bone marrow micrometastases in breast cancer patients. J Natl Cancer Inst 89: 1044- 1049

Fox SB, Gasparini G, Harris AL (2001) Angiogenesis: pathological, prognostic, and growth factor pathways and their link to trial design and anticancer drugs. Lancet Oncol 5: 278-289

Fridman V, Humblet C, Bonjean K, Boniver J (2000) Assessment of tumour angiogenesis in invasive breast carcinomas: absence of correlation with prognosis and pathological factors. Virchows Arch 437: 611-617

Fujioka S, Yoshida K, Yanagisawa S, Kawakami M, Aoki T, Yamazaki Y (2001) Angiogenesis in pancreatic carcinoma. Cancer 92: 1788-1797

Fukuda S, Shirahama T, Imazono Y, Tsushima T, Ohmori Y, Kayajima T, Take S, Nishiyama K, Yonezawa S, Akiba S, Akiyama S, Ohi Y (1999) Expression of vascular endothelial growth factor in patients with testicular germ cell tumours as an indicator of metastatic disease. Cancer 85: 1323 1330

Gasparini G, Bevilacqua P, Pozza F, Meli S, Weidner N (1993) P-glycoprotein expression predicts response to chemotherapy in previously untreated advanced breast cancer. Breast, 2: 27-32

Gasparini G, Weidner N, Bevilacqua P, Maluta S, Dalla Palma P, Caffo O, Barbareschi M, Boracchi P, Marubini E, Pozza F (1994) Tumour microvessel density, p53 expression, tumour size and peritumoral lymphatic vessel invasion are relevant prognostic markers in node-negative breast carcinoma. J Clin Oncol 12: 454-466

Gasparini G, Harris AL (1995) Clinical importance of determination of tumour angiogenesis in breast carcinoma: much more than a new prognostic tool. J Clin Oncol 13: 765-782

Gasparini G, Barbareschi M, Boracchi P, Verderio P, Caffo O, Meli S, Palma PD, Marubini E, Bevilacqua M (1995a) Tumour angiogenesis predicts clinical outcome of node-positive breast cancer patients treated either with adjuvant hormone therapy or chemotherapy. Cancer J Sci Am 1: 131-141 
Gasparini G, Bevilacqua P, Bonoldi E, Testolin A, Galassi A, Verderio P, Boracchi P, Gugliemi RB, Pezzella F (1995b) Predictive and prognostic markers in a series of patients with head and neck squamous cell invasive carcinoma treated with concurrent chemoradiation therapy. Clin Cancer Res 1: $1375-1383$

Gasparini G, Fox SB, Verderio P, Bonoldi E, Bevilacqua P, Boracchi P, Dante S, Marubini E, Harris AL (1996) Determination of angiogenesis adds information to oestrogen receptor status in predicting the efficacy of adjuvant tamoxifen in node-positive breast cancer patients. Clin Cancer Res 2: $1191-1198$

Gasparini G, Brooks PC, Biganzoli E, Vermeulen PB, Bonoldi E, Dirix LY, Ranieri G, Miceli R, Cheresh DA (1998) Vascular integrin $\alpha_{v} \beta_{3}$ : a new prognostic indicator in breast cancer. Clin Cancer Res 4: 2625-2634

Gasparini G, Harris AL (1999) Prognostic significance of tumour vascularity. In Antiangiogenic agents in cancer therapy, Teicher BA (ed) pp 317-339. Totowa, NJ: Humana Press

Gasparini G (2001) Clinical significance of determination of surrogate markers of angiogenesis in breast carcinoma. Crit Rev Oncol Haematol 37: $97-114$

Giatromanolaki A, Sivridis E, Brekken R, Thorpe PE, Anastasiadis P, Gatter KC, Harris AL, Koukourakis MI (2001) The angiogenic 'vascular endothelial growth factor/flk-1/KDR receptor' pathway in patients with endometrial carcinoma: Prognostic and therapeutic implications. Cancer 92: $2569-2577$

Goulding Hm, Abdul Rahid NF, Robertson JF, Bell JA, Elston CW, Blamey RW, Ellis IO (1995) Assessment of angiogenesis in breast carcinomas: an important factor in prognosis?. Hum Pathol 26: 1196-1200

Guidi AJ, Abu-Jawdeh G, Berse B, Jackman RW, Tognazzi K, Dvorak HF, Brown LF (1995) Vascular permeability factor expression and angiogenesis in cervical neoplasia. J Natl Cancer Inst 87: 1237-1245

Guidi AJ, Berry DA, Broadwater G, Perloff M, Norton L, Barcos MP, Hayes DF (2000) Association of angiogenesis in lymph node metastsases with outcome of breast cancer. I Natl Cancer Inst 92: 486-492

Hall NR, Fish DE, Hunt N, Goldin RD, Guillou PJ, Monson RT (1992) Is the relationship between angiogenesis and metastasis in breast cancer real? Surg Oncol 1: 223-229

Halvorsen OJ, Haukaas S, Hoisaeter PA, Akslen LA (2000) Independent prognostic importance of microvessel density in clinically localised prostate cancer. Anti Cancer Res 20: 3791 - 3799

Hansen S, Grabau DA, Sorensen FB, Bak M, Vach W, Rose C (2000) The prognostic value of angiogenesis by Chalkley counting in a confirmatory study design on 836 breast cancer patients. Clin Cancer Res 6: 139-146

Heiman R, Ferguson D, Powers C, Recant WM, Weichselbaum RR, Hellman S (1996) Angiogenesis as a predictor of long-term survival for patients with node-negative breast cancer. J Natl Cancer Inst 88: $1764-1769$

Hildenbrand R, Dilger I, Horlin A, Stutte HJ (1995) Urokinase and macrophages in tumour angiogenesis. Br J Cancer 72: 818-823

Hollingsworth HC, Kohn EC, Steinberg SM, Rothenberg ML, Merino MJ (1995) Tumour angiogenesis in advanced stage ovarian carcinoma. Am J Pathol 147: $33-41$

Horak ER, Leek R, Klenk N, LeJeune S, Smith K, Stuart N, Greenall M, Stepniewska K, Harris AL (1992) Angiogenesis assessed by platelet/endothelial cell adhesion molecule antibodies, as indicator of node metastases and survival in breast cancer. Lancet 340: $1120-1124$

Holthofer H, Virtanen I, Kariniemi AL, Hormia M, Linder E, Miettinen A (1982) Ulex Eurpaeus I lectin as a marker for vascular endothelium in human tissues. Lab Invest 47: 60-66

Huber S, Delorme S, Knopp MV, Junkermann H, Zuna I, von Fournier D, van Kaick G (1994) Breast tumours: Computer-assisted quantitative assessment with colour Doppler US. Radiology 192: 797-801

Jacquemier JD, Penault-Llorca P, Bertucci F, Sun ZZ, Houvenaeghel GF, Geneix JA, Puig BD, Bardou VJ, Hassoun JA, Birnbaum D, Viens PJ (1998) Angiogenesis as a prognostic marker in breast carcinoma with conventional adjuvant chemotherapy: a multiparametric and immunohistochemical analysis. J Pathol 184: $130-135$

Kamijo T, Yokose T, Hasebe T, Yonou H, Sasaki S, Hagashi R, Ebihara S, Miyahara H, Hosoi H, Ochigi A (2000) Potential role of microvessel density in predicting radiosensitivity of $\mathrm{T} 1$ and $\mathrm{T} 2$ stage laryngeal squamous cell carcinoma treated with radiotherapy. Clin Cancer Res 6: $3159-3165$

Kato T, Kimura T, Ishii N, Fujii A, Yamamoto K, Kameoka S, Nishikawa T, Kasajima T (1999) The methodology of quantitation of microvessel density and prognostic value of neovascularisation associated with long term survival in Japanese patients with breast cancer. Breast Cancer Res Treat 53: $19-31$
Kim KJ, Li B, Winer J, Armanini M, Gillett N, Phillips HS, Ferrara N (1993) Inhibition of vascular endothelial growth factor induced angiogenesis suppresses tumour growth in vivo. Nature 362: $841-844$

Kumar S, Ghellal A, Li C, Byrne G, Haboubi N, Wang JM, Bundred N (1999) Breast cancer: vascular density determined using CD 105 antibody correlates with tumour prognosis. Cancer Res 59: 856-861

Lane AM, Egan KM, Yang J, Saornil MA, Alroy J, Albert D, Gragoudas ES (1997) An evaluation of tumour vascularity as a prognostic indicator in uveal melanoma. Melanoma Res 7: 237-242

Linderholm B, Tavelin B, Grankvist K, Henrikkson R (1999) Does vascular endothelial growth factor (VEGF) predict local relapse and survival in radiotherapy treated node-negative breast cancer?. Br J Cancer 81: 727 732

Li VW, Folkerth RD, Watanabe H, Yu C, Rupnick M, Barnes P, Scott RM, Black PM, Sallen SE, Folkman J (1994) Microvessel count and cerebrospinal fluid basic fibroblast growth factor in children with brain tumours. Lancet 344: $82-86$

Liotta LA, Kleinerman J, Saidel GM (1974) Quantitative relationship of intravascular tumour cells, tumour vessels and pulmonary metastases following tumour implantation. Cancer Res 34: $997-1004$

Macaulay VM, Fox SB, Zhang H, Whitehouse RM, Leek RD, Gatter KC, Bicknell R, Harris AL (1995) Breast cancer angiogenesis and tamoxifen resistance. Endocrine-related Cancer 2: 97-103

Macchiarini P, Fontanini G, Hardin MJ, Squartini F, Angeletti CA (1992) Relation of neovascularisation to metastasis of non-small cell lung cancer. Lancet 340: 145 - 146

Maeda K, Chung YS, Takatsuka S, Ogawa Y, Sawada T, Yamashita Y, Onada N, Kato Y, Nitta A, Arimato Y (1995) Tumour angiogenesis as a predictor of recurrence in gastric carcinoma. J Clin Oncol 13: 477-481

Maeda K, Chung Y, Ogawa Y, Takatsuka S, Kang SM, Ogawa M, Sawada T, Sowa M (1996) Prognostic value of vascular endothelial growth factor expression in gastric carcinoma. Cancer 77: $858-863$

Maniotis AJ, Folberg R, Hess A, Seftor EA, Gardner LM, Pe'er J, Trent JM, Meltzer PS, Hendrix J (1999) Vascular channel formation by human melanoma cells in vivo and in vitro: vasculogenic mimicry. Am J Pathol 155: $739-752$

Martin L, Green B, Renshaw C, Lowe D, Rudland P, Leinster SJ, Winstanley J (1997) Examining the technique of angiogenesis assessment in invasive breast cancer. Br J Cancer 76: 1046-1054

Matsuura T, Kuratate I, Teramachi K, Osaki M, Fukuda Y, Ito H (1999) Thymidine phosphorylase expression is associated with both increase of intraturmoral microvessels and decrease of apoptosis in human colorectal carcinomas. Cancer Res 59: 5037-5040

Mattern J, Koomagi R, Volm M (1996) Association of vascular endothelial growth factor expression with intratumoral microvessel density and tumour cell proliferation in human epidermoid lung carcinoma. $\mathrm{Br} J$ Cancer 73: $931-934$

McCulloch P, Choy A, Martin L (1995) Association between tumour angiogenesis and tumour cell shedding into effluent venous blood during breast cancer surgery. Lancet 346: 1334-1335

Medri L, Nanni O, Volpi A, Scarpi E, Dubini A, Riccobon A, Becciolini A, Bianchi S, Amadori D (2000) Tumour microvessel density and prognosis in node-negative breast cancer. Int J Cancer 89: 74-80

Miettinen M, Lindenmayer AE, Chaubal A (1994) Endothelial cell markers CD31, CD34, and BNH 9 antibody to $\mathrm{H}$ - and $\mathrm{Y}$-antigens - evaluation of their specificity and sensitivity in the diagnosis of vascular tumours and comparison with von Willebrand factor. Mod Pathol 7: 82-90

Morphopoulos G, Pearson M, Ryder WD, Howell A, Harris M (1996) Tumour angiogenesis as a prognostic marker in infiltrating lobular carcinoma of the breast. J Pathol 180: $44-49$

Obermair A, Wasicky R, Kaider A, Preyer O, Losch A, Leodolter S, Kolbe H (1999) Prognostic significance of tumour angiogenesis in epithelial ovarian cancer. Cancer Lett 138: $175-182$

Ogawa Y, Chung Y-S, Nakata B, Takatsuka S, Maeda K, Sawada T, Kato Y, Yoshikawa K, Sakurai M, Sowa M (1995) Microvessel quantitation in invasive breast cancer by staining for factor VIII-related antigen. Br J Cancer 71: $1297-1301$

Oh-e H, Tanaka S, Kitadai Y, Shimamoto F, Yoshihara M, Haruma K (2001) Angiogenesis at the site of deepest penetration predicts lymph node metastasis of submucosal colorectal cancer. Dis Colon Rectum 44: 1129-1136

Olivarez D, Ulbright T, DeReise W, Foster R, Reister T, Einhorn L, Sledge G (1994) Neovascularisation in clinical stage A testicular germ cell tumour: prediction of metastatic disease. Cancer Res 54: 2800-2802 
Parums DV, Cordell JL, Micklem K, Heryet AR, Gatter KC, Mason DY (1990) JC70: a new monoclonal antibody that detects vascular endothelium associated antigen on routinely processed tissue sections. J Clin Pathol 43: $752-757$

Pezzella F, Pastorino U, Tagliabue E, Andreola S, Sozzi G, Gasparini G, Menard S, Gatter KC, Harris AL, Fox SB, Buyse M (1997) Non-small cell lung carcinoma tumour growth without morphological evidence of neoangiogenesis. Am J Pathol 151: 1417-1423

Riedel F, Gotte K, Schwalb J, Bergler W, Hermann K (2000) Coexpression of VEGF and bFGF is associated with increased vascular density in head and neck carcinomas. Laryngorhinootologie 79: 730-735

Rose C, Hansen S, Grabau DA et al (2000) Microvessel density as compared to the Chalkley count in a prognostic study of angiogenesis in breast cancer patients. Proc Am Soc Clin Oncol 19: p 1058 (Abstract 2580)

Saclarides TJ, Speziale NJ, Drab E, Szeluga DJ, Rubin DB (1994) Tumour angiogenesis and rectal carcinoma. Dis Colon Rectum 37: 921-926

Saleh M, Stacker SA, Wilks AF (1996) Inhibition of growth of C6 glioma cells in vivo by expression of anti-sense VEGF sequence. Cancer Res 56: $393-$ 401

Schmidt NO, Westphal M, Hagel C, Ergun S, Starrou D, Rosen EM, Lamszus K (1999) Levels of vascular endothelial growth factor, hepatocyte growth factor/scatter factor and basic fibroblast growth factor in human gliomas and their relation to angiogenesis. Int J Cancer 84: 10-18

Schor AM, Pendleton N, Pazouki S, Smither RL, Morris J, Lessan K, Heerkens E, Chandrachud LM, Carmichael G, Adi M, Chisholm DM, Stevenson H (1998) Assessment of vascularity in histological sections: effects of methdology and value as an index of angiogenesis on breast tumours. Histochem J 30: 849-856

Slaton JW, Inoue K, Perrotte P, El-Naggar AK, Swanson DA, Fidler IJ, Dinney CP (2001) Expression levels of genes that regulate metastasis and angiogenesis correlate with advanced pathological stage of renal cell carcinoma. Am J Pathol 158: $735-743$

Smith K, Fox SB, Whitehouse R, Taylor M, Greenall M, Clarke J, Harris AL (1999) Up regulation of basic fibroblast growth factor in breast carcinoma and its relationship to vascular density, oestrogen receptor, epidermal growth factor receptor and survival. Ann Oncol 10: 707-713

Srivastava A, Laidler P, Hughes LE, Woodcock J, Shedden EJ (1986) Neovascularisation in human cutaneous melanoma: a quantitative morphologcal and Doppler ultrasound study. Eur J Cancer Clin Oncol 22: 1205-1209

Srivastava A, Laidler P, Davies RP, Horgan K, Hughes LE (1988) The prognostic significance of tumour vascularity in intermediate-thickness $(0$ 76-4.0 mm thick) skin melanoma: a quantitative histologic study. Am J Pathol 133: 419-423

Straume O, Salvesen HB, Akslen LA (1999) Angiogenesis is prognostically important in vertical growth phase melanomas. Int J Oncol 15: 59-99

Sugamoto T, Tanji N, Sato K, Fujita H, Nishio S, Sakanaka M, Yokoyama M (2001) The expression of basic fibroblast growth factor and vascular endothelial growth factor in prostatic adenocarcinoma: correlation with neovascularisation. Anticancer Res 21: 77-88

Takahashi Y, Kitadai Y, Bucana CD, Cleary KR, Ellis LM (1995) Expression of vascular endothelial growth factor and its receptor, KDR, correlates with vascularity, metastasis and proliferation of human colon cancer. Cancer Res 55: 3964-3968

Takahashi Y, Cleary KR, Mai M, Kitadai Y, Bucana CD, Ellis LM (1996) Significance of vessel count and vascular endothelial growth factor and its receptor (KDR) in intestinal type gastric cancer. Clin Cancer Res 2: $1679-1684$

Takano S, Yoshii Y, Kondo S, Suzuki H, Maruno T, Shirai S, Nose T (1996) Concentration of vascular endothelial growth factor in the serum and tumour tissue of brain tumour patients. Cancer Res 56: 2185-2190

Tanaka F, Otake Y, Yanagihara K, Kawano Y, Miyahara R, Li M, Yamada T, Hanaoka N (2001) Evaluation of angiogenesis in non-small cell lung cancer: Comparison between anti-CD34 antibody and anti-CD105 antibody. Clin Cancer Res 7: 3410-3415

Tanigawa N, Amaya H, Matsumara M, Shimomatsuya T (1997) Association of tumour vasculature with tumour progression and overall survival of patients with non-early gastric carcinomas. $\mathrm{Br} J$ Cancer 75: 566-571

Toi M, Inada K, Hoshina S, Suzuki H, Kondo S, Tominaga T (1995a) Vascular endothelial growth factor and platelet-derived endothelial cell growth factor are frequently coexpressed in highly vascularised human breast cancer. Clin Cancer Res 1: 961-964

Toi M, Inada K, Suzuki H, Tominaga T (1995b) Tumour angiogenesis in breast cancer: its importance as a prognostic indicator and the association with vascular endothelial growth factor expression. Breast Cancer Res Treat 36: $193-204$
Toi M, Kondo S, Suzuki H, Yamamoto Y, Inada K, Imazawa T, Taniguchi T, Tominaga T (1996) Quantitative analysis of vascular endothelial growth factor in primary breast cancer. Cancer 77: 1101-1106

Traweek ST, Kandalaft PL, Mehta P, Battifora H (1991) The human haematopoietic progenitor cell antigen (CD34) in vascular neoplasia. AM J Clin Pathol 96: 25-31

Tynninen O, Aronen HJ, Ruhala M, Paetau A, Von Boguslawski K, Salonen O, Jaaskelainen J, Paavonen T (1999) MRI enhancement and microvascular density in gliomas. Correlation with tumour cell proliferation. Invest Radiol 34: 427-434

Ueda M, Terai Y, Kumagai K, Ueki K, Okamoto Y, Ueki M (1999) Correlation between tumour angiogenesis and expression of thymidine phosphorylase, and patient outcome in uterine cervical carcinoma. Hum Pathol 30: $1389-1394$

Vacca A, Ribatti D, Roncali L, Ranieri G, Serio G, Silvestris F, Dammacco F (1994) Bone marrow angiogenesis and progression in multiple myeloma. Br I Haematol 87: $503-508$

Van Dijke CF, Brasch RC, Roberts TP, Weidner N, Mathur A, Shames DM, Mann JS, Demsar F, Lang P, Schwickert HC (1996) Mammary carcinoma model: correlation of macromolecular contrast-enhanced MR imaging, characterisations of tumour microvasculature and histologic capillary density. Radiology 198: $813-818$

Van Diest PJ, Zevering JP, Zevering LC, Baak JP (1995) Prognostic value of microvessel quantitation in cisplatin treated stage 3 and 4 ovarian cancer patients. Pathol Res Pract 191: 25-30

Van Hoef ME, Knox WF, Dhesi SS, Howell A, Schor AM (1993) Assessment of tumour vascularity as a prognostic factor in lymph node negative breast cancer. Eur I Cancer 29A:: 1141 - 1145

Vermeulen PB, Verhoeven D, Fierens H, Hubens G, Goovaerts G, van Marck E, De Bruijn EA, van Oosterom AT, Dirix LY (1995) Microvessel quantification in primary colorectal carcinoma: an immunohistochemical study. Br J Cancer 71: 340-343

Vermeulen PB, Gasparini G, Fox SB, Toi M, Martin L, McCulloch P, Pezzella F, Viale G, Wiedner N, Harris AL, Dirix LY (1996) Quantification of angiogenesis in solid human tumours: an international consensus on the methodology and criteria of evaluation. Eur J Cancer 32A: 2474-2484

Vermeulen PB, Libura M, Libura J, O'Neill PJ, Van Dam P, van Marck E, van Oosterom AT, Dirix LY (1997) Influence of investigator experience and microscopic field size on microvessel density in node-negative breast carcinoma. Breast Cancer Res Treat 42: 165-172

Vermeulen PB, van den Eynden GG, Huget P, Goovaerts G, Weyler J, Lardon F, van Marck E, Hubens G, Dirix LY (1999) Prospective study of intratumoral microvessel density, p53 expression and survival in colorectal cancer. Br J Cancer 79: 316-322

Viens P, Jacqueimer J, Bardou VJ, Bertucci F, Penault-Llorca F, Puig B, Gravis G, Oziel-Taieb S, Resbuet M, Hovenaeghel G, Camerlo J, Birbaum D, Hassoun J, Maranichi D (1999) Association of angiogenesis and poor prognosis in node-positive patients receiving anthracycline-based adjuvant chemotherapy. Breast Cancer Res Treat 54: 205-212

Vincent-Salomon A, Carton M, Zafrani B, Freneaux P, Nicolas A, Massemin B, Fourquet A, Clough K, Pouillart P, Sastre-Garau X (2001) Long term outcome of small size invasive breast carcinomas independent of angiogenesis in a series of 685 cases. Cancer 92: 249-256

Visscher DW, Smilanetz S, Drozdowicz S, Wykes SM (1993) Prognostic significance of image morphometric microvessel enumeration in breast carcinoma. Analyte Quant Cytol Histol 15: 88-92

Wakui S, Furusato M, Itoh T, Saraki H, Akiyama A, Kinoshita I, Asano K, Tokuda T, Aizawa S, Ushigome S (1992) Tumour angiogenesis in prostatic carcinoma with and without bone marrow metastases: a morphometric study. J Pathol 168: 257-262

Weidner N, Semple JP, Welch WR, Folkman J (1991) Tumour angiogenesis and metastasis - correlation in invasive breast carcinoma. $N$ Engl J Med 324: $1-8$

Weidner N, Folkman J, Pozza F, Bevilacqua P, Allred EN, Moore DH, Meli S, Gasparini G (1992) Tumour angiogenesis: a new significant and independent prognostic indicator in early-stage breast carcinoma. J Natl Cancer Inst 84: $1875-1887$

Weidner N, Carroll PR, Flax J, Blumenfeld W, Folkman J (1993) Tumour angiogenesis correlates with metastasis in invasive prostate carcinoma. Am J Pathol 143: 401-409

Weidner N, Gasparini G (1994) Determination of epidermal growth factor provides additional prognostic information to measuring tumour angiogenesis in breast carcinoma patients. Breast Cancer 29: 97-107 
Wang JM, Kumar S, Pye D, Haboubi N, al-Nakib L (1994) Breast carcinoma: comparative study of tumour vasculature using two endothelial cell markers. J Natl Cancer Inst 86: $386-388$
Xiangming C, Hokita S, Natsugoe S, Tanabe G, Baba M, Takao S, Kuroshima K, Aikou T (1998) Angiogenesis as an unfavorable factor related to lymph node metastasis in early gastric cancer. Ann Surg Oncol 5: 585-589 